\title{
On the life history of the marine plankton diatom Stephanopyxis palmeriana
}

\author{
Gerhard Drebes \\ Biologische Anstalt Helgoland, Meeresstation, Helgoland ${ }^{1}$
}

\begin{abstract}
KURZFASSUNG: Zur Entwicklungsgeschichte der marinen Planktondiatomee Stepbanopyxis palmeriana. Im Frühjahr 1964 wurde die zentrische Planktondiatomee Stepbanopyxis palmeriana (GREv.) GRUNOW - eine aus japanischen Gewässern stammende Warmwasserform und unserer $S$. turris sehr nahe verwandt - in Kultur genommen. Schon nach kurzer Zeit war es möglich, den gesamten Formwechsel dieser Alge in seinen Grundzügen kennenzulernen. Mit Hilfe von Wasserimmersionen konnten in direkter Lebendbeobachtung Zellteilung, Meiosis, Befruchtung und Auxosporenbildung mit ihren metagamen Mitosen sowie die Bildung und Keimung der Dauersporen studiert werden. Morphologisch stimmt der Formwechsel mit dem von S. turris (v. STOSCH \& DREBES 1964) überein; in der Abhängigkeit von Umweltfaktoren bestehen jedoch Unterschiede. So werden Dauersporen bei dieser zwischen 19 und $156 \mu$ Zellbreite ( $=$ Transversaldurchmesser) vegetativ existierenden Alge nur von schmalen, unter $90 \mu$ breiten Zellen in Gegenwart von Phosphatmangel (spärlich manchmal auch bei Nitratmangel) differenziert. Eine Temperatur von $12^{\circ} \mathrm{C}$ wirkt dabei sehr begünstigend. Die Keimung der Dauersporen setzt nach Beseitigung des Phosphatmangels ein. Zur Sexualisierung sind nur unter $60 \mu$ breite Zellen fähig; sie findet statt nach sprunghafter Steigerung der Beleuchtungsstärke (von 400 auf $4000 \mathrm{Lux}$ ) sowie einer Temperaturerhöhung von $15^{\circ}$ auf $21^{\circ} \mathrm{C}$. Wegen der Dickschaligkeit bereitet die Anderung der Zellgröße auf künstlichem Wege durch $\mathrm{SiO}_{2}$-Mangel mit nachfolgender Schalenregeneration einige Schwierigkeiten. Diese Manipulationen sind jedoch notwendig, wenn ein Klon ohne Veränderung seines Idiotypus über die Auxospore für unbegrenzte Dauer zur Verfügung stehen soll.
\end{abstract}

\section{INTRODUCTION}

After many years of investigation we succeeded in manipulating the complete life cycle of Stephanopyxis turris under controlled laboratory conditions (v. STоsсH \& DREBES 1964), thus paving the road for culturing other species of the same genus. If the few species described by GRunow (1884) from the Arctic Ocean near Franz Josef Land, which are difficult to obtain, are excluded, there are three remaining species available as study objects: the warm-water form $S$. palmeriana, $S$. orbicularis from the coastal waters of New Zealand and S. nipponica from the northern North Pacific. Fortunately, a culture of $S$. palmeriana was kindly put at my disposal by Dr. H. TAKaNo of Tokyo.

1 The studies were carried out in the Botanical Institute of the University, Marburg. 
S. palmeriana does not occur in northern Europe and is very seldom found along the southern European coasts. Since this species is often confused with the closely related species $S$. turris, its distribution is not clearly known. According to HusTEDT (1930) S. palmeriana seems to be restricted to the warm seas, the Indian Ocean and the Pacific. Culturing $S$. palmeriana offered interesting insights into morphological and physiological features of a warm-water species.

\section{MATERIAL AND METHODS}

Stephanopyxis palmeriana (GRev.) Grunow was obtained from a plankton sample dated November 1, 1963, taken by Mr. OMORI at $33^{\circ} 20^{\prime} \mathrm{N}, 139^{\circ} 00^{\prime} \mathrm{E}$, on board the "Tansei-maru", a ship owned by the Oceanographical Institute of the Tokyo University. Dr. TAKano isolated the alga and kept it in a fully synthetic medium, where it grew very well. On April 21, 1964, the alga arrived at my previous laboratory in the Botanical Institute of the University of Marburg. The immediate transfer into our half-synthetic nutritional medium (Table 1) was successful. The composition of this medium is identical with the one used for $S$. turris.

Table 1

Nutritional medium (after v. STOSCH \& Drebes 1964) used in experiments

\begin{tabular}{|c|c|c|}
\hline Composition & Weight (mg) & $\begin{array}{l}\text { Portion of most important } \\
\text { elements }(\mu \mathrm{g})\end{array}$ \\
\hline $\begin{array}{l}\text { Sea water (North Sea) } \\
\mathrm{Na} \mathrm{NO}_{3} \\
\mathrm{Na}_{2} \mathrm{HPO}_{4} \times 12 \mathrm{H}_{2} \mathrm{O} \\
\mathrm{FeSO}_{4} \times 7 \mathrm{H}_{2} \mathrm{O} \\
\mathrm{MnCl}_{2} \times 4 \mathrm{H}_{2} \mathrm{O} \\
\mathrm{SiO}_{2} \\
\mathrm{Na}_{2} \mathrm{EDTA} \times 2 \mathrm{H}_{2} \mathrm{O} \\
\text { Vitamin } \mathrm{B}_{12}\end{array}$ & $\begin{array}{l}1020000 \\
42.5 \\
10.75 \\
0.278 \\
0.0198 \\
12 \\
3.72 \\
0.0007\end{array}$ & $\begin{array}{ll}7000 & \mathrm{~N} \\
930 & \mathrm{P} \\
55.8 & \mathrm{Fe} \\
5.9 & \mathrm{Mn} \\
5.6 & \mathrm{Si}\end{array}$ \\
\hline
\end{tabular}

No test was undertaken to see whether or not $S$. palmeriana exhibits vitamin $B_{12}$ auxotrophy. The alga was kept as a unialgal culture at the vegetative stage in small Jena Glass Petri dishes (diameters of 5 or $6 \mathrm{~cm}$ ) exposed to a constant temperature of $15^{\circ} \mathrm{C}$ at a light intensity of $400 \mathrm{Lux}$; in addition, other constant temperatures between $9^{\circ}$ and $24^{\circ} \mathrm{C}$ were offered in order to take the alga through its complete life cycle. The light-dark rhythm was $16: 8$ hours at $15^{\circ} \mathrm{C}$ and $14: 10$ hours (light phase: $8 \mathrm{a} . \mathrm{m}$. to 12 midnight and 8 a.m. to $10 \mathrm{p} . \mathrm{m}$. respectively) at all other temperatures. The observation in vivo was done with a microscope (having a sea water proof immersion objective, $50: 1$, N. A. 1.00, Leitz-Wetzlar), which was dipped into the culture dishes. For a discussion of nutritional requirements and detailed methods, see v. SтовсH \& Drebes (1964). 


\section{MORPHOLOGY AND MANIPULATION OF CELL SIZE}

The frustule structure of this alga as seen through a light microscope (Hustedt 1930) clearly distinguishes it from $S$. turris. In addition, the wall and structure of the frustule are thicker and more strongly developed in $S$. palmeriana than in $S$. turris.

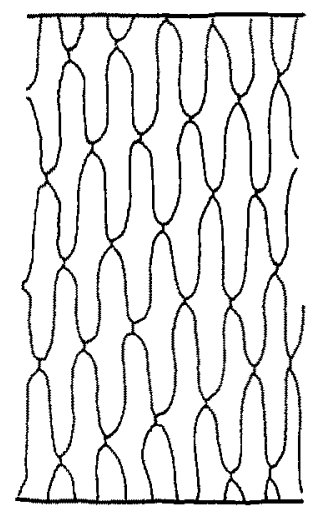

Fig. 1: Structure of the pleura of Stephanopyxis palmeriana, drawn from a photograph $(510 \times)$

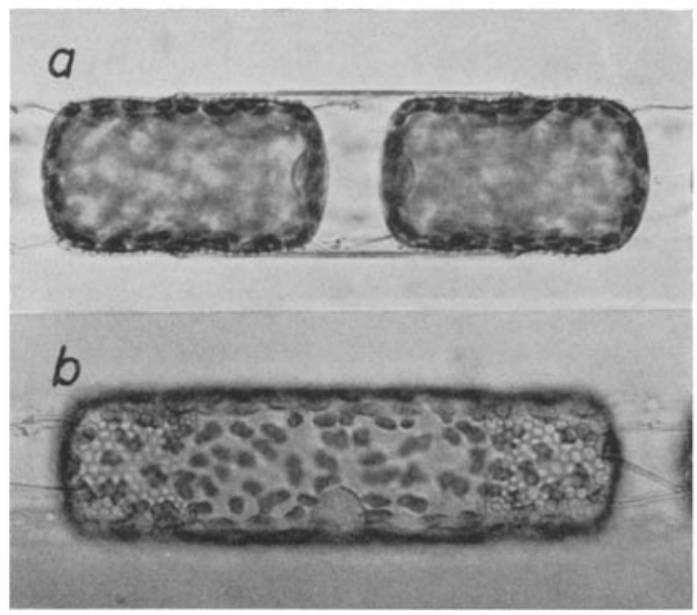

Fig. 2: S. palmeriana. (a) A pair of cells with interphasic nucleus located in the discus of the hypovalva; (b) elongated cell shortly before cell division, nucleus in the equator of the cell $(450 \times)$

As has been the case earlier in S. turris (v. STOSCH \& DREBES 1964), the pleural structure of $S$. palmeriana was unknown. It was made visible after skeletonization in Eau-de-Javelle, washing in distilled water and treating with $0.1 \%$ crystal-violet solution (Fig. 1). Such treatment revealed the same structural properties as in $S$. turris and S. orbicularis, in which Cassre \& Bentaud (1960) observed a pleural fragment 
using electronoptical techniques. This new type of pleural structure seems to be a characteristic of the genus Stephanopyxis.

Another characteristic of Stephanopyxis is the interphasic location of the cell nucleus in the discus of the hypovalva (Fig. 2a). A "nucleus central" in S. palmeriana had been reported earlier by GRAN \& ANGST (1931), as shown in Figure 2b. However, this stage corresponds to the stretch phase just before cell division, when the inner girdle (hypopleura) is simultaneously formed. The interphasic nucleus is known for

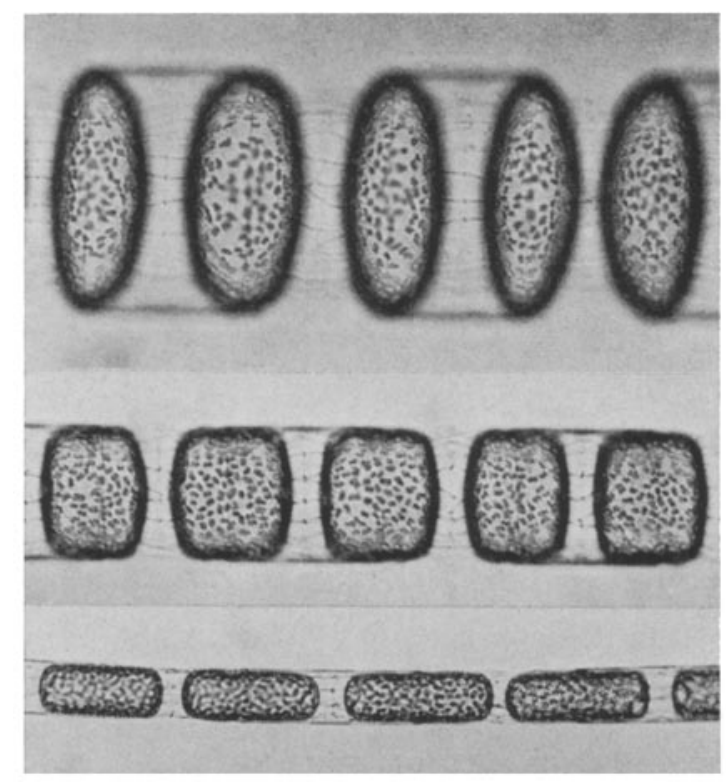

Fig. 3: S. palmeriana. Three cell chains of various cell diameters (200X)

certain to lie in the discus of the epivalva in the closely related genus Melosira (v. STOSCH 1951, 1958, Drebes unpublished) and after further investigations, also in Podosira montagnei, Pyxidicula mediterranea and Hyalodiscus spec. (DreBes unpublished). All these genera, including Stephanopyxis, have been placed in the sub-family Melosirinae by HusTEDT (1930). He gives the cell diameter for $S$. palmeriana as 35 to $150 \mu$, and Cupp (1943) 27 to $71 \mu$. In culture the diatom divided down to $19 \mu$ wide cells; in measuring cells of freshly germinated auxospores, the maximum diameter was found to be $156 \mu$. Figure 3 shows three cell chains of various cell diameters.

Since the life cycle of diatoms, the formation of auxospores and also of resting spores are a function of cell size (GeItrer 1932, v. STOSCH \& Drebes 1964), an attempt was made to obtain as quickly as possible "subclones" of different cell widths from a $100 \mu$-clone during the vegetative phase. Very old cultures containing cells already partly deformed received a fresh nutritional solution. Thereafter, elongated, sandglassshaped strangulated cells were often able by continous cell division to form cell chains of smaller diameters. Such regenerates were isolated as new subclones. Thus within 
two months, cell material with the following diameters were made available: $100 \mu$, $66 \mu, 56 \mu$ and $36 \mu$. When smaller cells were cultured in $\mathrm{SiO}_{2}$-deficient solution, they often could enlarge by plasma protrusion; in order to get frustule regeneration after enlargement, $\mathrm{SiO}_{2}$ solution was added again. This procedure, however, caused some difficulties; according to the previously mentioned degree of frustule thickness, the regenerated algal cells require a very long time to reach normal shape again. For a detailed discussion of the problem and technique of cell size manipulation during the vegetative phase, see v. STosch (1965).

\section{SEXUAL REPRODUCTION AND AUXOSPORE FORMATION}

Aside from an observation by GRAN \& ANGST (1931), who only once found a single cell with eight "microspores", nothing is known about sexual processes and auxospore formation. As the findings about the main characteristics of $S$. turris (v. STOSCH \& DREBES 1964) agree with those of S. palmeriana, a short discussion with a few illustrations should be adequate.

As was expected, only cells in the lower part of cell size range are capable of sexualization. Their diameter lies between $19 \mu$ and about $60 \mu$. Taking into consideration the cell size as an endogenous, non-genetic factor, abundant formation of gametes occurs only if $S$. palmeriana - previously kept at $15^{\circ} \mathrm{C}$ and $400 \mathrm{Lux}$ - is exposed for at least 1.5 to 2 days to light intensities between 3000 and 5000 Lux and a temperature of $21^{\circ} \mathrm{C}$. In contrast to $S$. turris, the increase in light intensity alone is not sufficient to initiate sexualization in $S$. palmeriana (in only one case was a single cell containing spermatogonia found at $15^{\circ} \mathrm{C}$ ). Thus the warm-water living $S$. palmeriana exhibits significantly higher temperature requirements for sexual reproduction.

Like all centric diatoms studied up to now, $S$. palmeriana is monoecious, one clone producing male and female gametes. With the beginning of the 14-hour light phase, the male determined cell, in two or three depauperizing mitoses, forms four, six or eight spermatogonia, which are enclosed in the mother cell (spermatogonangium). Each spermatogonium is surrounded by two rudimentary valves. Figure 4 shows some of the stages of spermatogonia formation. By undergoing meiosis the spermatogonia swell, a process which usually opens the spermatogonangium (Fig. $4 \mathrm{~d}$ ). The moment in which the meiosis begins depends on the number of cell divisions during the formation of the spermatogonia. After only two depauperizing mitosis meiosis begins earlier than after three (Fig. 5b). The metakinesis $I$ of meiosis becomes visible by a shrinkage of the vacuole and is followed by shrinkage of the whole protoplast (Fig. 5). Both meiotic nuclear divisions are not accompanied by cytokinesis. The flagella develop during the interkinesis as in all other Centrales so far studied. When the reduction divisions are completed, the four nuclei of a spermatocyte, which are surrounded only by a small amount of cytoplasma, detach themselves as uniflagellate, colorless sperms (Fig. 5). The remaining mass of cytoplasma and all plastids form a dying rest-body. This type of spermatogenesis is termed me roge nous (Melosira type).

In contrast to the formation of spermatogonia by depauperizing mitoses, the 
oogonia develop directly from vegetative cells. Increased multiplication of plastids, considerable elongation of the cell and the swollen nucleus (Fig. 6a), observable under a dissection microscope $(40 \mathrm{X})$, make it possible to distinguish the oogonia easily from the vegetative reproduction phases. The meiotic divisions take place without cyto-

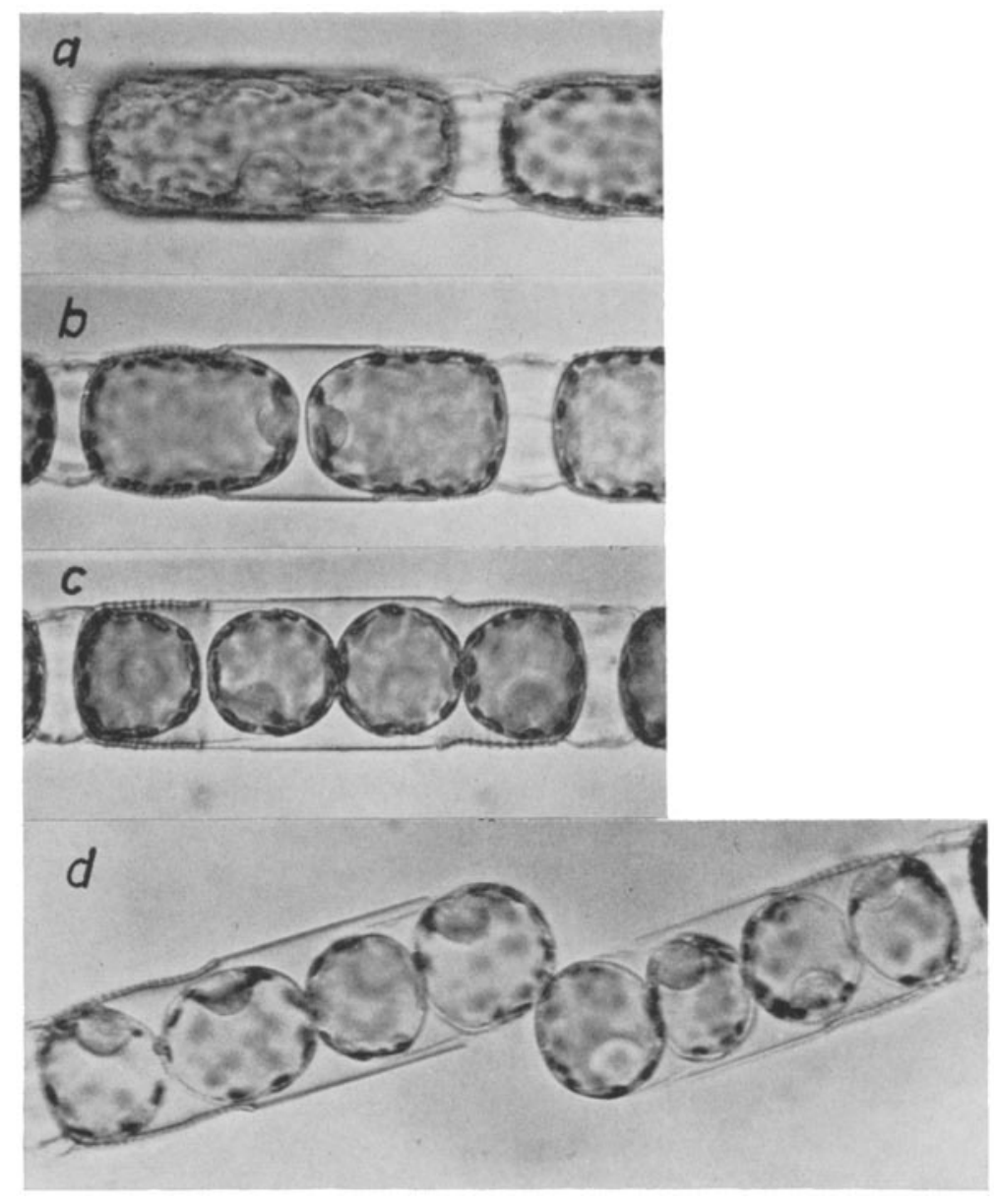

Fig. 4: Some stages of spermatogonia formation in S. palmeriana. (a) Cell just before the first, (b) after the first, (c) after the second, (d) after the third depauperizing mitosis; in (d) the swollen spermatogonia undergoing meiosis have opened the spermatogonangium (450X)

kinesis; after each nuclear division one nucleus becomes pycnotic. The peculiar process of nuclear abortion has been recorded in detail for $S$. turris (v. STOSCH \& Drebes 1964). At the end of this process the mature egg contains one haploid nucleus and two pycnotic nuclei (Fig. 6b). The meiosis occurs simultaneously with that of the spermatocytes at the end of the 14 hour light phase. In comparison to $S$. turris the formation of gametes in $S$. palmeriana is completed about two hours earlier. 
Following meiosis the oogonium stretches until its pleurae totally separate; this action leads to a slight bending of the cell (Fig. 6b,c). Between the openings of the two pleurae the partially exposed female protoplast comes into contact with the external medium. In this way penetration of the sperm into the egg is made possible; during penetration the motile organelle of the sperm, the flagellum, is discarded. After passing through the plasmalemma, the small, homogenously colored sperm nucleus

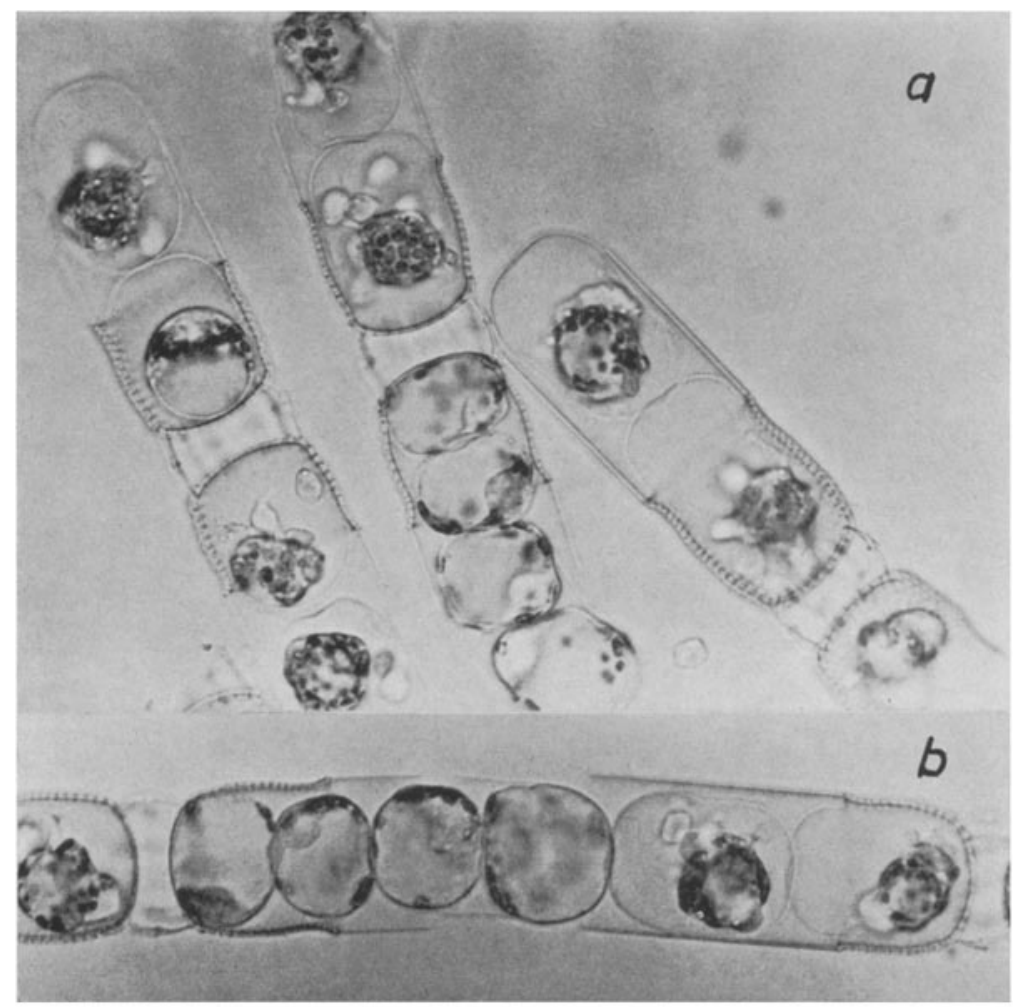

Fig. 5: S. palmeriana. (a) Various stages of meiosis with formation of colorless sperms. Note the rudimentary, thin and spineless valvae of the spermatogonia. (b) Spermatogonangium containing six spermatogonia, the four at the left formed by three, the two at the right by only two depauperizing mitoses. The four spermatogonia on the left side started meiosis later $(450 \times)$

slowly approaches within 2 to 6 minutes the great transparent egg nucleus, which contains 1 to 2 nucleoles, and attaches itself to it. Meanwhile a contraction of the protoplast closes the oogonium again. In the course of the next half hour the male nucleus swells, becomes reticulate, and finally a thread-like structure of chromosomes (Fig. 6d) appears. Then the male chromosomes - wandering along the periphery of the female nucleus - enter the oogon nucleus from all sides. On the basis of cytological data and observations on living material, v. STOSCH \& Drebes (1964) had already assumed that this fundamental process took place in a similar manner in $S$. turris. In 


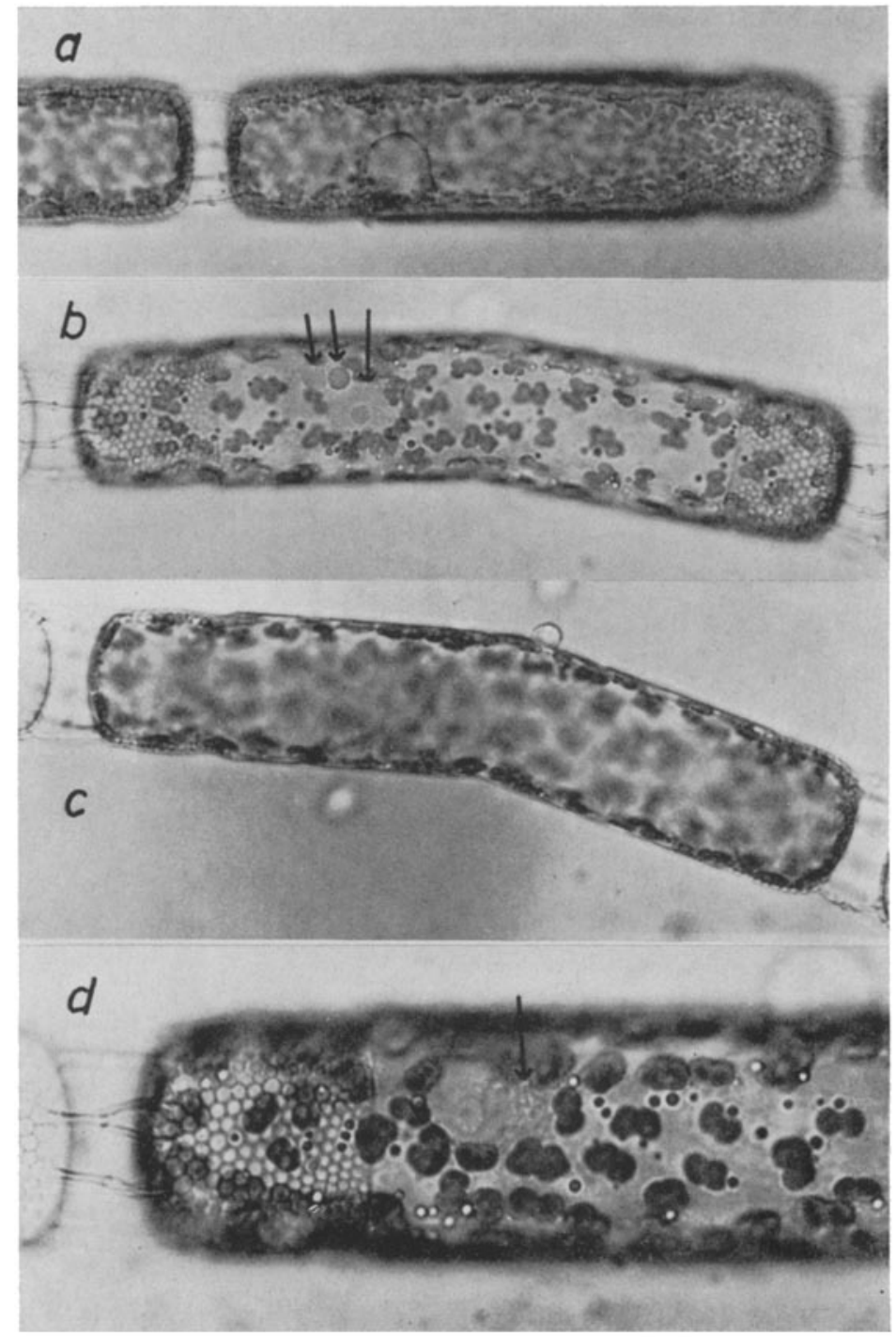

Fig. 6: S. palmeriana. Formation of the female gamete and fertilization. (a) Oogonium in meiotic prophase (swollen nucleus); (b) mature egg containing one surviving haploid nucleus (right arrow) with a central nucleolus and two small pycnotic nuclei (two left arrows); (c) slightly bent, opened oogonium with sperm on its surface; (d) stage of karyogamy. Arrow points to the chromosomes of the male nucleus (a to $c: 450 \times ; d: 750 \times$ )

S. palmeriana it was now possible to clearly observe the whole process of karyogamy in vivo.

Preceding the subsequent light phase, the zygote contracts and then - increasing in size and assuming the shape of a sphere with two protrusions (Fig. 7) - the auxo- 
spore is formed. During the light phase the auxospore forms its first two valvae; these are secreted in two subsequent steps, the second beginning some 7 hours after the first one, and in each case preceded by a metagamic mitosis. The resulting valvae lack the girdles and the circlets of spines. During the stretching initiating the first cell division,

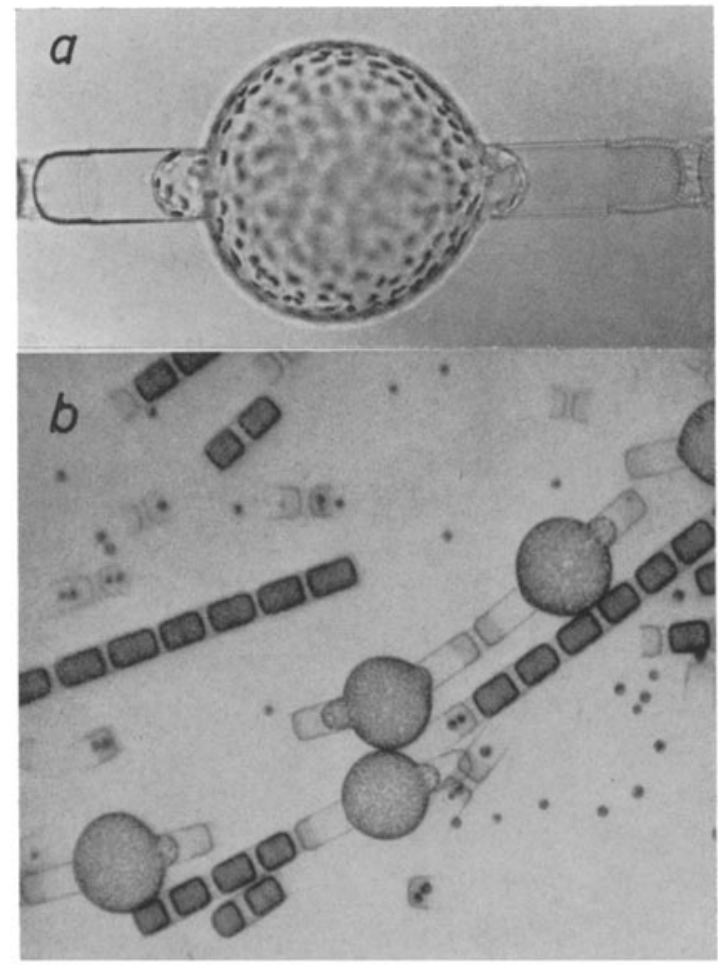

Fig. 7: S. palmeriana. (a) The zygote has inflated to an auxospore; (b) four auxospores, vegetative cell chains and empty valvae with small rest bodies left over after spermatogenesis ( $a: 216 \times ; b: 55 \times)$

both an epipleura and a hypopleura are developed. The epipleura, somewhat shorter and of abnormal structure, has an irregular, polygonal areolation, which was already designated as a "praepleura" in S. turris (v. STOSCH \& DREBES 1964). During the first cell division the fertilization membrane (auxospore membrane) bursts, and thus a new clone of larger cells is born.

\section{RESTING SPORES}

In $S$. palmeriana resting spores are known to exist in nature and have been described by Gran \& ANGST (1931). Their formation takes place in two differentiating divisions, in the same manner as in $S$. turris. Observations on my cultures showed 
that in the early stage the first cell division does not differ from a normal vegetative reproduction division. The character of a heterovalvate division, which indicates resting spore formation, becomes apparent only during the secretion of the new daughter valvae, which are thicker, shorter and more strongly areolated. Before the

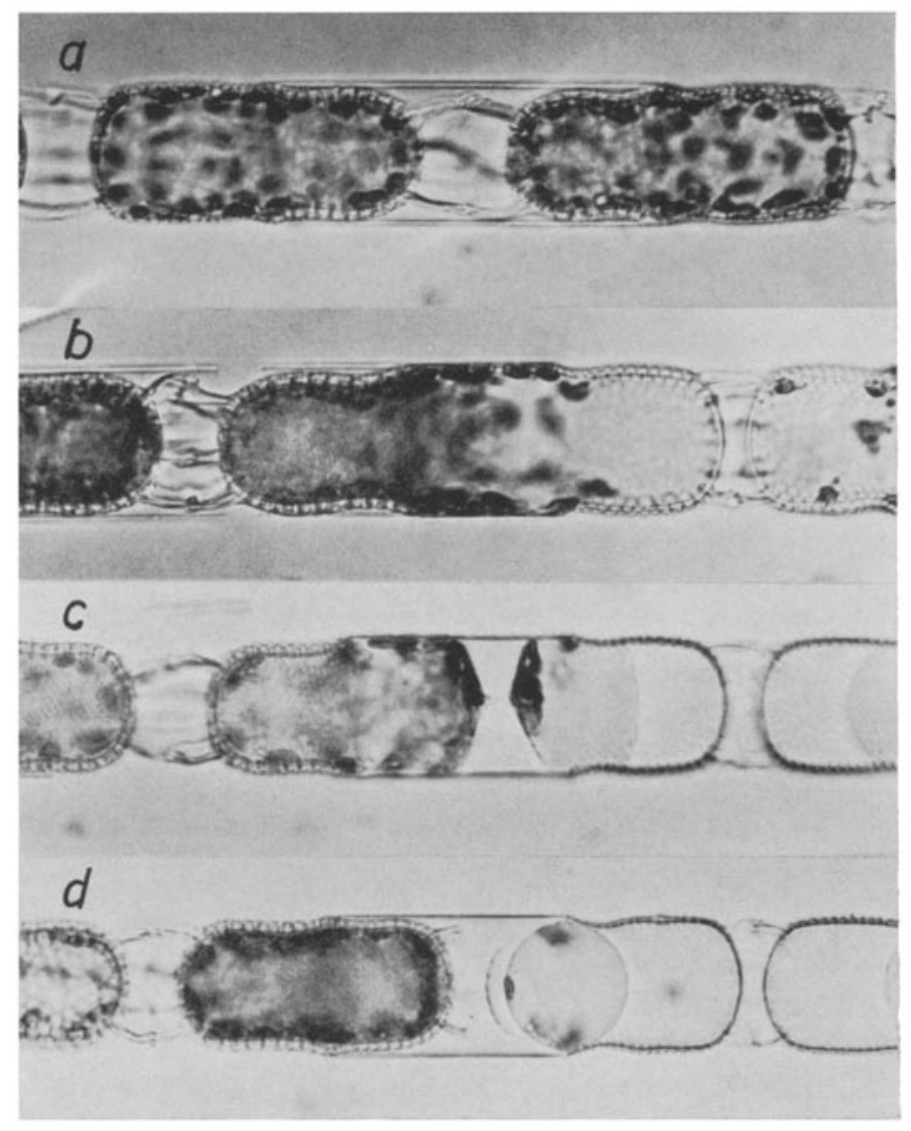

Fig. 8: Resting spore formation of $S$. palmeriana. (a) Two heterovalvate cells, each containing the first spore valva; (b) heterovalvate cell during polarization of the cell content, plastids leaving the epivalva; (c) extremely unequal cell division with (d) formation of the resting spore and a small, later disintegrating body. Note the rudimentary thin valva of this body $(450 \times)$

second cell division a polarization in the protoplast, which is recognizable by the migration of the plastids (Fig. 8b), occurs. Finally, after the cell content concentrates in the prospective spore-side, all the plastids vacate the entire epivalva and part of adjacent epipleura. Thus an extremly inequal cytokinesis follows (Fig. 8c), which produces the resting spore by secreting the second spore valva, and only a small body with a nucleus and a few plastids remains. This later disintegrating body still develops a rudimentary, sandglass-shaped valva (Fig. $8 \mathrm{~d}$ ). The spines of the second spore valva 
do not diverge and do not taper as in $S$. turris, but are nearly parallel to the pervalvar axis and have blunt ends (Fig. 8d).

Germination of the resting spore occurs in the same way as in S. turris, by elongation of the cell and normal cell division. The spore valvae are used further by the germinated cells. According to Michallowa (1962), who first described a resting spore germination, the spore valvae in the species Chaetoceros lauderi RALFS are discarded during germination.

Which conditions induce the production of resting spores in $S$. palmeriana? In order to find an answer to this important question, three series of experiments were conducted. In the first series various constant temperature levels (between $9^{\circ}$ and $24^{\circ} \mathrm{C}$ ) were offered. No formation of resting spores was observed. In the second series the possible influence of cell size was analyzed by using different subclones of various cell diameters. Again, this treatment did not produce any resting spores. Finally, in the third series of experiments, the possible importance of nutritive substances was tested. Because phosphate and nitrate represent two of the most important minimum factors in the sea, nutritional solutions were used without the additional doses of phosphate and nitrate, respectively. Cultures inoculated with a few short cell chains and exposed to a temperature of $12^{\circ} \mathrm{C}$ (light intensity of about $1200 \mathrm{Lux}$ ) started to form resting spores in the state of phosphate-deficiency after 6 to 7 days. In most cases nitrate deficiency did not produce resting spores at all, in a few cases only sporadically. Probably the most intensive effect on resting spore formation is created by a nutritional medium lacking both phosphate and nitrate. Among the temperature levels offered $\left(9^{\circ}, 12^{\circ}, 15^{\circ}, 18^{\circ}, 21^{\circ}\right.$ and $\left.24^{\circ} \mathrm{C}\right) 12^{\circ} \mathrm{C}$ proved to be most effective. However, resting spore formation took place, although very occasionally, at temperatures up to $24^{\circ} \mathrm{C}$.

In the existing diatom literature nothing was known about the influence of cell size on the formation of resting spores. The first pertinent data on $S$. twris were published by Drebes (1964) and v. STosch \& Drebes (1964), who found that only cells of a large diameter (30 to $97 \mu$ ) are capable of resting spore formation. According to newer information (Drebes unpublished) this range can be extended to $115 \mu$ (Fig. 9). The relation between cell size on resting spore formation is completely different in S. palmeriana. In the first experiment with $100 \mu$ and $66 \mu$ wide cells, only the latter formed resting spores. Further studies showed resting spore formation down to $19 \mu$ cell diameter, the lower limit of vegetative existence. A $100 \mu$ clone, as well as a clone consisting of cells of $150 \mu$ diameter, which originated from a just germinated auxospore, never produced any resting spores. Resting spores occurred only after the cell diameter decreased to $90 \mu$.

The resting spores germinated after they were transferred into a fresh, complete nutritional solution, which compensated for the deficiencies suffered in the previous culture medium. 


\section{COMPARISON OF VITAL DATA OBTAINED FOR $S$. TURRIS AND S. PALMERIANA}

Besides $S$. turris, a further test-case model, $S$. palmeriana, is presented for studying the complete life history of a marine planktonic diatom in the laboratory. The transparence of this alga allows direct observation of its fundamental nuclear processes, such as meiosis and karyogamy, under a light microscope. These two species may therefore easily be used as classroom specimens for university students and as research subjects for developmental physiology.

\section{S.palmeriana}

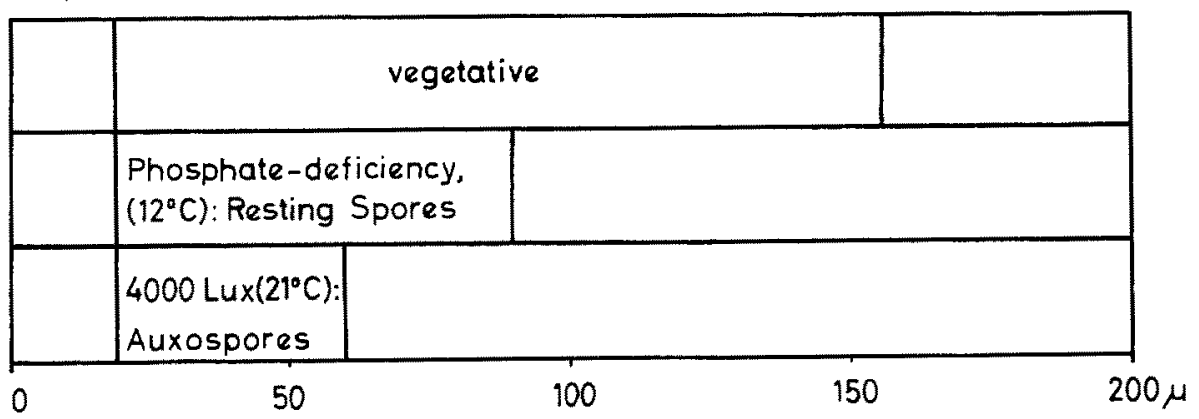

\section{S. turris}

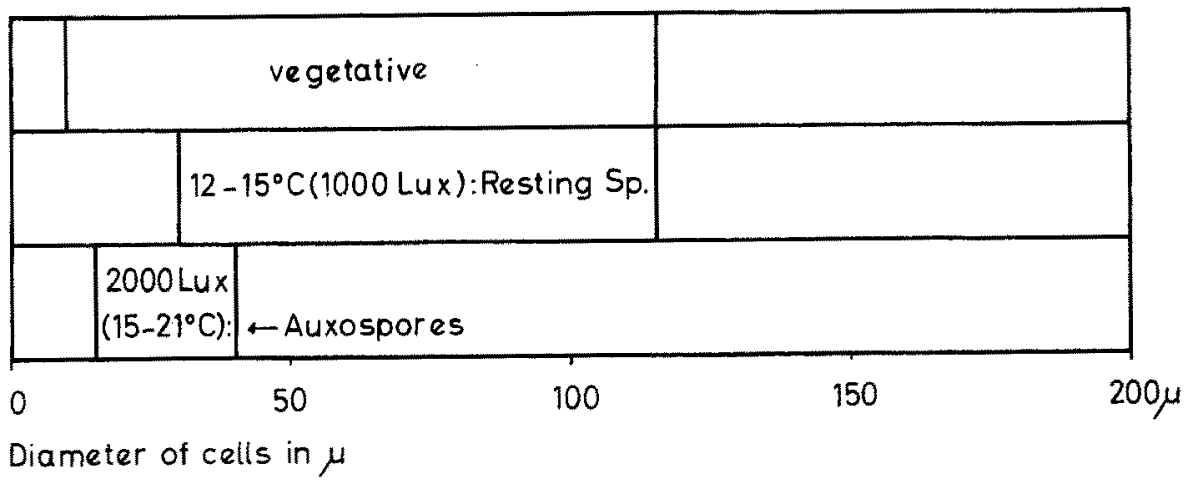

Fig, 9: Important internal and external factors controlling the life histories of $S$, turris and S. palmeriana. Diagrammatic illustration

The most important internal and external factors controlling the life histories of $S$. turris and $S$. palmeriana are diagrammatically illustrated in Figure 9 . As can be seen from this figure cell size, temperature, light and nutrients decisively control the phases of the life cycles. A comparison of the information (only the optimal conditions are recorded here) obtained for the temperate $S$. turris and the warm-water species $S$. palmeriana is given below: 
Vegetative phase: cell size 10 to $115 \mu$; Resting spores (middle line): cell size 30 to $115 \mu$, temperature $12^{\circ}$ to $15^{\circ} \mathrm{C}$, light $1000 \mathrm{Lux}$; A u x os pores (lower line): cell size 15 to $40 \mu$, temperature $15^{\circ}$ to $21^{\circ} \mathrm{C}$, light $2000 \mathrm{Lux}$.

\section{Stephanopyxis palmeriana}

Vegetative phase : cell size 19 to $156 \mu$; Resting spores (middle line): cell size 19 to $90 \mu$, temperature $12^{\circ} \mathrm{C}$, nutrients phosphate-deficiency; A u x o spores (lower line): cell size 19 to $60 \mu$, temperature $21^{\circ} \mathrm{C}$, light 4000 Lux.

One reason for the fact that $S$, palmeriana avoids colder waters may be the high temperature requirements for sexualization. The influences of both internal and external factors on the formation of resting spores are quite different in these two species. Unfortunately, the taxonomic identity of these closely related species has frequently been misjudged, consequently, their geographical distribution is not clearly known. Further investigations are necessary in order to obtain a sound basis for a discussion of the first results obtained in laboratory cultures.

\section{SUMMARY}

1. The cell diameter of Stephanopyxis palmeriana ranges between 19 and $156 \mu$. The pleural structure is considered to be specific for the genus. The interphasic nucleus lies in the discus of the hypovalva.

2. The cell size can be manipulated during the vegetative phase through $\mathrm{SiO}_{2}$-deficiency followed by frustule regeneration.

3. Only 19 to $60 \mu$ wide cells are capable of forming gametes and auxospores. Differentiation begins after light intensity is suddenly increased from 400 to 4000 Lux, and temperature from $15^{\circ}$ to $21^{\circ} \mathrm{C}$.

4. Only 19 to $90 \mu$ wide cells are capable of forming resting spores. These are produced in the presence of phosphate-deficiency; maximum production occurs at $12^{\circ} \mathrm{C}$. After correction of the phosphate-deficiency, resting spores germinate.

5. Morphologically, the life history (formation of gametes, auxospores, resting spores) conforms essentially with the findings on Stephanopyxis turris (v. STOscH \& DREBES 1964).

6. The most important factors controlling the life cycle are cell size, temperature, light and nutrients. The effects which these factors produce in $S$. turris are compared with those observed in S. palmeriana. 


\section{ACKNOWLEDGMENTS}

The writer wishes to express his thanks to Dr. H. Takano (Tokyo) for making the alga available and to Professor H. A. von Srosch (Marburg) for the use of his laboratory in which the experiments were carried out. I am also very indebted to Miss F. W. Crouse for her great help in translating the paper into English.

\section{LITERATURE CITED}

Cassie, V. \& Bertaud, W. S., 1960. Electron microscope studies of New Zealand marine plankton diatoms. Jb. microse. Soc. 79, 89-94.

Cupp, E. E., 1943. Marine plankton diatoms of the West Coast of North America. Bulll. Scripps Instn Oceanogr. tech. Ser. 5, 1-237.

Drebes, G., 1964. Uber den Lebenszyklus der marinen Planktondiatomee Stephanopyxis turris (Centrales) und seine Steuerung im Experiment. Helgoländer wiss. Meeresunters. 10, $152-153$.

Geitler, L., 1932. Der Formwechsel der pennaten Diatomeen (Kieselalgen). Arch. Protistenk. $78,1-226$.

Gran, H. H. \& Angst, E. C., 1931. Plankton diatoms of Puget Sound. Publs Puget Sound mar. biol. Stn 7, 417-516.

Grunow, A., 1884. Die Diatomeen von Franz-Josephs-Land. Denkschr. Akad. Wiss., Wien 48, 53-112.

HustedT, F., 1930. Die Kieselalgen ... T. 1. In: L. Rabenhorst's Kryptogamenflora von Deutschland, Österreich und der Schweiz. Akad. Verl. Ges., Leipzig, Bd 7, 1-920.

Michailowa, N. F., 1962. On the germination of resting spores of Chatoceros lauderi Ralfs. Dokl. Akad. Nawk SSSR 143,741-742.

Stosch, H. A. von, 1951. Entwidklungsgeschichtliche Untersuchung an zentrischen Diatomeen. 1. Die Auxosporenbildung von Melosira varians. Arch. Mikrobiol. 16, 101-135.

- 1958. Entwicklungsgeschichtliche Untersuchungen an zentrischen Diatomeen. 3. Die Spermatogenese von Melosira moniliformis AGARDH. Arch. Mikrobiol. 31, 274-282.

- 1965. Manipulierung der Zellgröße von Diatomeen im Experiment. Pbycologia 5, 21-44.

StosCh, H. A, von \& DREBES, G., 1964. Entwicklungsgeschichtliche Untersuchungen an zentrischen Diatomeen. 4. Die Planktondiatomee Stephanopyxis twrris, ihre Behandlung und Entwicklungsgeschichte. Helgoländer wiss. Meeresunters. 11, 209-257. 